\title{
How Does It Feel To Be A Problem? Being Young and Arab in America
}

\author{
by Moustafa Bayoumi
}

Published by Penguin Books, 2008, 270 pages

Reviewed by:

Courtney Cassard (courtney.cassard@nicholls.edu), Director of Enrollment Services, Nicholls State University

Throughout American history, many Americans with diverse backgrounds have been unjustly discriminated against by the social, political, and religious circumstances of the time. Native Americans labeled "Indian Savages" in the Declaration of Independence, Irish and Italian Catholic Immigrants accused of loyalty to religion over the republic, German Americans ostracized during World War I, Japanese Americans quarantined in training camps during World War II, and African Americans being considered property were all considered unique "problems" of the era. We have all been taught that to be American is not about being judged by our religion, ethnicity, or gender, but rather, by the content of our character.

There is, however, a population of Americans living in a post 9/11 reality who are continually asked to apologize for acts they did not commit or condone. Virtually all Arab Americans - of Muslim, Christian, Jewish, or no faith at all — were just as horrified by the heinous acts as any other American. The aftermath of the attacks, and the fear spread throughout the world, has caused people to make generalizations about Arab and Muslim Americans that are unfair and unfounded. This book is the story of seven young Arab Americans living in Brooklyn and their experiences after September 11, 2001.

Bayoumi introduces the reader to seven twenty-somethings living in Brooklyn, New York. Rasha, a university student, came to the United States from Syria when she was five years old. Although Rasha was Muslim, her parents were not particularly religious. Instead of teaching her components of Islam, they focused on teaching Rasha the values of honesty, compassion, and honor. A few days into her first semester of college, Rasha's family was detained due to an immigration discrepancy. They were shackled and sent to three different jails. Three months later, they were released. There are countless examples of people, both legal and undocumented, being detained after September 11.

Readers are introduced to Sami, who is 24 years old and going back to college. He was born in America to an Egyptian Christian mother and a Palestinian father who arrived in the U.S. in 1949. Sami joined an Arab club at his university where he would often get into heated arguments about the wars in Iraq and Afghanistan. Even though he was critical of the wars, he was firmly behind the U.S. troops; however, Sami lost a good friend to what he came to believe was useless violence overseas in Iraq.

Additional stories illustrate how Arab Americans, some Muslim, often feel like outsiders in their communities. College students may relate to these young people because they are facing some of the same issues, including stress over romantic relationships, finishing college, starting a career, and trying to figure out a place in the world. This book sheds light on a group of people who may be misunderstood, either because they are not heard from or because the media only cover the most sensationalistic aspects of their culture. This book provides a wonderful opportunity for discussion on what should unite young people, rather than on the differences that outside influences sometimes highlight and inflame.

There may be some areas of concern from some constituencies. There is discussion of the 
policies that led up to some of the experiences that these young people faced. In many instances, but not all, opinions critical of the Bush administration come from the young people rather than from the author. Perhaps it would benefit both critics and proponents of the wars to put ideologies aside and have an honest discussion of how the events during and following September 11 affected people from all walks of life. This book is enlightening for readers who do not encounter large groups of Muslim or Arab Americans on a regular basis.

There are many areas of the book that are rich with discussion opportunities. The characters in this book will provide a baseline of experience to the inevitable memorials on the 10th anniversary of September 11. First-year history students could discuss similarities of these circumstances that Arab Americans are facing and how their experiences may be similar or different from other groups considered a "problem," such as African Americans, Japanese Americans, Jewish citizens, and gay and lesbian Americans.

Another application of the book could be in communication classes where students could discuss Al Jazeera and its impact on world opinion. This can be done through the eyes of one of the characters in the book, Omar, who graduates with honors in communications but has difficulty finding a job, and worries because he completed an internship at Al Jazeera News Network. Since many Americans are not aware that there is an English Al Jazeera network (available as a free streaming iPhone application), there is a good opportunity to explore the network and how it serves a larger purpose than broadcasting Bin Ladin audio messages.

Other topics from the book might be relevant for students studying sociology. Some of the discussions could focus on characters in the book and their group-think. For instance, the book relays a story of a young Muslim mother in a hijab who got on the bus carrying a sleeping baby under a blanket. An older couple on the bus started to discuss what the young mother could be concealing and, before long, the words "terrorist" and "bomb" started wafting through the bus. A man confronted the bus driver and threatened to call the police unless the bus driver checked the young mother to be sure that she was just carrying a sleeping child. Given this scenario, issues such as racial profiling or bystander behavior might be good discussion topics. This story takes place in Brooklyn, New York, which is known for its rich tradition of diversity. Students could discuss whether the experiences highlighted in this book would have been different if Bayoumi had chosen subjects from the South, or the West Coast, or Dearborn, Michigan.

A plethora of rich cultural diversity programming activities could occur with this book as a background. Panels where Arab or Muslim students could answer questions from those who may never have learned about Middle Eastern culture or Islam would benefit all involved. There is a good chance that "Westernized" students would come away with an idea that their Arab or Muslim counterparts are in many ways, more similar to them than different from them. For example, since food often unites people, campus food service operations could offer themed dishes that are indigenous to regions in the Middle East. In addition, there are many documentary movies available on the origins and practices of Islam that could be shown in the classroom or elsewhere on campus. It could also be interesting to include activities urging students to wear some form of Muslim clothing, such as a head scarf, and go out into the community and then reflect on their experience.

As educators, we must provide opportunities for all students to learn from each other, listen to opposing thoughts and ideas, and understand and respect each other. Bayoumi's book is a good introduction to issues of discrimination and culture that deserve our attention. 